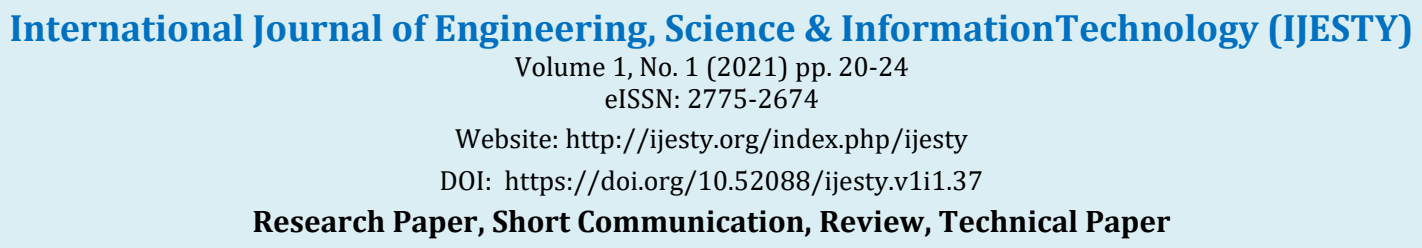

\title{
Determinant Analysis Of Conflict On Project Results In Aceh Province
}

\author{
Rinaldy*, Muhammad Ikhsan \\ Faculty of Engineering, Universitas Teuku Umar, Meulaboh, Aceh, Indonesia \\ *Corresponding author E-mail: rinaldy@utu.ac.id
}

Manuscript received 1 Jan 2021; revised 10 Jan 2021; accepted 15 Jan 2021. Date of publication 20 Jan 2021

\begin{abstract}
The project is an activity with a target that must be completed within a certain period, where in its implementation often obstacles arise between the elements involved in it. Problems that arise must be immediately handled properly and appropriately so that the achievement of results is as expected.. Conflict is a condition of the oc-currence of discrepancies between values or goals to be achieved, both existing in individuals and in relationships with others. The purpose of this research is to find out one of the main factors causing conflict in project implementation. The method used in this study is a combined method, namely quantitative and qualitative methods through the distribution of questionnaires with the limitation of project observations from 2009-2011 that have been completed, with funding coming from the Aceh Budget (APBA). Designation of respondents for all classifications of construction services, from medium classification (M) to large classification (B). Population Construction executing services from the data obtained were 502 contractors, using the Slovin formula found a sample of 84 contractors. The independent variables reviewed are the owner factor and the project condition factor, while the dependent variable is the success of the project. To analyze data using multiple linear regression with the help of Product Solutions and Statistical Services (SPSS) version 22, while the statistical analysis performed in data processing is to test the validity and reliability. Based on research shows that the owner factor is one of the maint factors that cause conflict in project implementation in Aceh Province.
\end{abstract}

Keywords: Conflict, success, project, owner, project conditions

\section{Introduction}

The construction project is a series of activities that are only done once and are generally short-term [1]. In implementing a project all parties involved certainly hope that the project can be completed in accordance with the expected objectives. Expected objectives include that the project is completed on time, does not exceed the stipulated budget and quality is met [2]. Organizations are needed for the smooth implementation of a project [3]. Construction projects involve interactions between project elements (stakeholders), which include owners, consultants, contractors and subcontractors. In the project implementation process, the four elements interact with one another. Cooperation, coordination, and communication are very important to make a project successful.

Problems in project implementation will occur if the expected results are not appropriate and not achieved. Problems that arise must be immediately handled properly and appropriately between the elements involved in it so that the achievement of results is as expected. Conflict is a condition of a discrepancy between values or goals to be achieved, both those that exist within individuals and within do with other people. Many factors can cause conflict, one of them is the owner factor and the project condition factor. The factors that have been mentioned can affect the efficiency and productivity of work, so that it will interfere with project implementation. In resolving conflicts that occur in construction projects, organizations / contractors need effective management to manage conflicts by identifying, and analyzing the causes of conflicts [4]. In addition, the contractor must also know about methods to resolve conflicts. Thus the conflicts that have occurred can be managed well so that the expected project objectives can be achieved.

In the construction phase, conflicts that often arise are unclear authority and responsibility, placement of personnel not in accordance with their expertise, design and specification errors, equipment and material delays, inaccurate cost estimates and approaches to dealing with problems [5]. Other research shows that there are four types of potential conflicts in building construction projects, namely conflicts due to organizational factors, conflicts due to technical factors, conflicts due to resource factors, and conflicts due to schedule factors. However, these conflicts have a frequency that is low enough to occur [6]. The purpose of this study is to find out one of the main factors causing conflict in the implementation of a project in Aceh Province. 


\section{Methods}

This study uses a combined method (mixed method), a method that combines qualitative and quantitative approaches. Qualitative methods are used to get respondents' perceptions in words, from the Likert scale used in the questionnaire. In this case the form of the word in question is starting from very no effect, no effect, less influential, influential, and very influential. Quantitative methods are used to get numbers on perceptions obtained from respondents. In this case the number in question is the respondent's answer score starting from $1,2,3,4$ and 5, which is then analyzed to obtain R count, Cronbach Alpha, and the mean value.

\subsection{Test Validity}

Validity test used to measure the validity or validity of an instrument in this case is a questionnaire [7]. This validity test can be formulated as follows.

$$
\mathrm{r}_{\mathrm{xy}}=\frac{N \sum X Y-\left(\sum X\right)\left(\sum Y\right)}{\sqrt{\left\{N \sum X^{2}-\left(\sum X\right)^{2}\right\}\left\{N \sum Y^{2}-\left(\sum Y\right)^{2}\right\}}}
$$

Where:

rxy = correlation coefficient between variables $\mathrm{X}$ and $\mathrm{Y}$;

$\sum X \quad=$ Number of scores obtained from respondents who were tested;

$\sum Y \quad=$ Total score of all items of all respondents tested; and

$\mathrm{N} \quad=$ Number of respondents.

The criteria for evaluating the validity test are if $\mathrm{R}$ count $>\mathrm{R}$ table then the questionnaire question items are valid, and vice versa if $\mathrm{R}$ count $<\mathrm{R}$ table then the questionnaire question items are invalid.

\subsection{Reliability Test}

The instrument is said to be reliable if the instrument can consistently bring up the same results every time a measurement is made [7] . This reliability test can be formulated as follows.

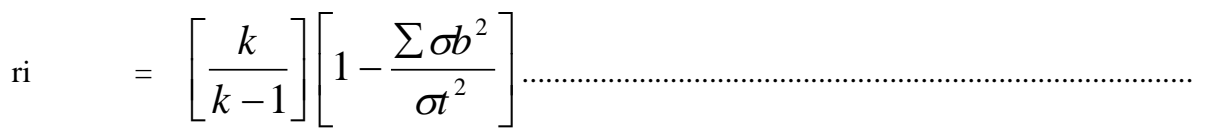

Where:

ri = Instrument reliability;

$\mathrm{k}=$ Number of questions;

$\sum \sigma b^{2}=$ Number of item variants; and

$\sigma t^{2}=$ Total variance.

The formula for item variance and total variance is as follows.

$\sigma b^{2}=\frac{\sum x^{2}-\frac{\left(\sum x^{2}\right)}{N}}{N}$

$\sigma t^{2}=\frac{\text { the sum of the squares of the total score }-\frac{\text { the sum of the squares of the total score }}{N}}{N}$

Where:

$\Sigma \times 2=$ Number of squares of variance per item; and

$\mathrm{N} \quad=$ Many respondents.

The criterion for evaluating the reliability test is that if Cronbach Alpha $>0.6$ then the variable in the questionnaire is reliable, and vice versa if Cronbach Alpha $<0.6$ then the variable in the questionnaire is not reliable [8].

\subsection{Descriptive Analysis}

Descriptive analysis is a statistic that serves to describe or give a description of the object under study through sample data or population as it is, without conducting analysis and making conclusions that are applicable to the public [9]. In this descriptive statistic, methods for presenting data with regular tables and frequency distributions, line and bar graphs, pie charts, pictograms, group explanations through 
mode, median, mean, and group variation through standard ranges and deviations will be presented. The mean can be formulated as follows.

$\mathrm{Me}=\frac{\sum x_{i}}{n}$

Where:

Me = Mean (average);

$\sum \quad=$ Sigma (number);

$\mathrm{Xi} \quad=$ value of $\mathrm{x}$ to $\mathrm{i}$ to $\mathrm{n}$; and

$\mathrm{n} \quad=$ Number of respondents [10].

\subsection{Conflict (Dispute)}

Conflict can be defined as a collision between opposing elements or thoughts in the project [11]. Conflict can be interpreted as a disagreement between two or more members of the organization or groups in the organization that arises because they have to use scarce resources together, or carry out activities together, or have the status, goals, values, and perceptions that are different [12].

\subsection{Conflict during Construction Implementation Stage}

The complexity of the work, limited time, the amount of resources used, and many more things that affect the process of construction. If these obstacles are not immediately overcome it will be able to cause harm and will lead to conflict. Conflicts in the implementation stage occur when what is stated in the contract does not match what is done in the field.

\section{Results And Discussion}

\subsection{Test Validity}

Validity test is used to determine the validity of an item statement on the questionnaire given to respondents. Test criteria if the value of $\mathrm{R}$ count $>\mathrm{R}$ table, then the statement item is valid, conversely if the value of $\mathrm{R}$ count $<\mathrm{R}$ table, then the statement item is invalid. The results of validity tests that have been processed through SPSS software are presented in Table 2.

Table 1. Test Validity

\begin{tabular}{|c|c|c|c|c|c|}
\hline No. & Variable & statement item & $\mathrm{R}_{\text {count }}$ & $\mathrm{R}_{\text {table }}$ & Information \\
\hline \multirow[t]{7}{*}{1} & \multirow[t]{7}{*}{ Owner factor (X1) } & $\mathrm{X}_{1.1}-\mathrm{X}_{1}$ & 0,907 & 0,212 & Valid \\
\hline & & $\mathrm{X}_{1.2}-\mathrm{X}_{1}$ & 0,889 & 0,212 & Valid \\
\hline & & $X_{1.3}-X_{1}$ & 0,899 & 0,212 & Valid \\
\hline & & $X_{1.4}-X_{1}$ & 0,840 & 0,212 & Valid \\
\hline & & $\mathrm{X}_{1.5}-\mathrm{X}_{1}$ & 0,938 & 0,212 & Valid \\
\hline & & $X_{1.6}-X_{1}$ & 0,740 & 0,212 & Valid \\
\hline & & $\mathrm{X}_{1.7}-\mathrm{X}_{1}$ & 0,826 & 0,212 & Valid \\
\hline \multirow[t]{21}{*}{2} & \multirow{21}{*}{$\begin{array}{l}\text { Project conditions factor } \\
\text { (X2) }\end{array}$} & $X_{2.1}-X_{2}$ & 0,882 & 0,212 & Valid \\
\hline & & $X_{2.2}-X_{2}$ & 0,911 & 0,212 & Valid \\
\hline & & $\mathrm{X}_{2.3}-\mathrm{X}_{2}$ & 0,877 & 0,212 & Valid \\
\hline & & $X_{2.4}-X_{2}$ & 0,945 & 0,212 & Valid \\
\hline & & $X_{2.5}-X_{2}$ & 0,749 & 0,212 & Valid \\
\hline & & $\mathrm{X}_{2.6}-\mathrm{X}_{2}$ & 0,792 & 0,212 & Valid \\
\hline & & $X_{2.7}-X_{2}$ & 0,873 & 0,212 & Valid \\
\hline & & $\mathrm{X}_{2.8}-\mathrm{X}_{2}$ & 0,903 & 0,212 & Valid \\
\hline & & $\mathrm{X}_{2.9}-\mathrm{X}_{2}$ & 0,877 & 0,212 & Valid \\
\hline & & $\mathrm{X}_{2.10}-\mathrm{X}_{2}$ & 0,464 & 0,212 & Valid \\
\hline & & $X_{2.11}-X_{2}$ & 0,600 & 0,212 & Valid \\
\hline & & $\mathrm{X}_{2.12}-\mathrm{X}_{2}$ & 0,460 & 0,212 & Valid \\
\hline & & $X_{2.13}-X_{2}$ & 0,861 & 0,212 & Valid \\
\hline & & $X_{2.14}-X_{2}$ & 0,863 & 0,212 & Valid \\
\hline & & $X_{2.15}-X_{2}$ & 0,939 & 0,212 & Valid \\
\hline & & $\mathrm{X}_{2.16}-\mathrm{X}_{2}$ & 0,767 & 0,212 & Valid \\
\hline & & $X_{2.17}-X_{2}$ & 0,794 & 0,212 & Valid \\
\hline & & $X_{2.18}-X_{2}$ & 0,869 & 0,212 & Valid \\
\hline & & $\mathrm{X}_{2.19}-\mathrm{X}_{2}$ & 0,903 & 0,212 & Valid \\
\hline & & $\mathrm{X}_{2.20}-\mathrm{X}_{2}$ & 0,823 & 0,212 & Valid \\
\hline & & $X_{2.21}-X_{2}$ & 0,789 & 0,212 & Valid \\
\hline
\end{tabular}




\begin{tabular}{|c|c|c|c|c|c|}
\hline & & $\mathrm{X}_{2.22}-\mathrm{X}_{2}$ & 0,816 & 0,212 & Valid \\
\hline \multirow[t]{13}{*}{3} & \multirow[t]{13}{*}{ Project success (Y) } & $\mathrm{Y}_{1}-\mathrm{Y}$ & 0,916 & 0,212 & Valid \\
\hline & & $Y_{2}-Y$ & 0,920 & 0,212 & Valid \\
\hline & & $Y_{3}-Y$ & 0,971 & 0,212 & Valid \\
\hline & & $\mathrm{Y}_{4}-\mathrm{Y}$ & 0,882 & 0,212 & Valid \\
\hline & & $Y_{5}-\mathrm{Y}$ & 0,929 & 0,212 & Valid \\
\hline & & $\mathrm{Y}_{6}-\mathrm{Y}$ & 0,800 & 0,212 & Valid \\
\hline & & $Y_{7}-Y$ & 0,837 & 0,212 & Valid \\
\hline & & $Y_{8}-Y$ & 0,884 & 0,212 & Valid \\
\hline & & $\mathrm{Y}_{9}-\mathrm{Y}$ & 0,949 & 0,212 & Valid \\
\hline & & $\mathrm{Y}_{10}-\mathrm{Y}$ & 0,927 & 0,212 & Valid \\
\hline & & $Y_{11}-Y$ & 0,370 & 0,212 & Valid \\
\hline & & $Y_{12}-Y$ & 0,578 & 0,212 & Valid \\
\hline & & $\mathrm{Y}_{13}-\mathrm{Y}$ & 0,390 & 0,212 & Valid \\
\hline
\end{tabular}

\subsection{Reliability Test}

The reliability test is used to determine whether a variable in the questionnaire given to the respondent is reliable or not. The criteria for testing this reliability test if the Cronbach Alpha value on a variable $>0.6$ then the reliable variable, and the variable is not reliable if the Cronbach Alpha value on the variable is <0.6. The reliability test results that have been processed through SPSS software are summarized in Table 2

Table 2 Reliability Tests

\begin{tabular}{clcc}
\hline No. & Variable & Cronbach Alpha $>0,6$ & Information \\
\hline 1 & Owner factor $\left(\mathrm{X}_{1}\right)$ & 0,960 & Reliable \\
2 & Project conditions factor $\left(\mathrm{X}_{2}\right)$ & 0,975 & Reliable \\
3 & Project success $(\mathrm{Y})$ & 0,957 & Reliable \\
\hline
\end{tabular}

The table above shows that all statement items studied have a value of $\mathrm{R}$ count $>\mathrm{R}$ table. Thus the validity test conducted on all statements on the questionnaire is all valid, so that it can proceed with the reliability test.

\subsection{Descriptive Analysis}

Descriptive analysis is used to determine contractors' perceptions about one of the main factors as a cause of conflict in the realization of construction project activities. Following are the results of each factor summarized in table 3 using SPSS version 22.

Table 3 Mean Factors Causing Conflict

\begin{tabular}{clccc}
\hline No. & & Variable & Mean & the ranking \\
\hline 1 & Owner factor $\left(\mathrm{X}_{1}\right)$ & 4,253 & 1 \\
\hline 2 & Project conditions factor $\left.\mathrm{X}_{2}\right)$ & 4,239 & 2 \\
\hline
\end{tabular}

The table above, shows that the results of the identification of the mean on the factors causing the conflict, has a mean value with the interval approaching. For the project condition factor, the result of calculation is 4,239 and the owner's factor is calculated by 4,253 . This means that in the implementation of construction projects based on the perception of the contractor one of the main factors causing conflict is the owner factor and the project condition factor with the highest value the main factor causing the conflict is the owner factor with a value of 0,014 higher than the project condition factor. This owner factor consists of 14 indicators, including winning the lowest bidder (contractor and consultant mentality), unrealistic expectations of the owner, failure to respond to problems in a timely manner, different interpretations of meaning in contract documents, failure to appoint a project manager, absence spirit team, approval (approval) regarding the value of costs or drawings of proposals or programs not being completed, resulting in delays in work, unclear mechanisms for providing information requests, poor management, supervision and coordination, late payment from the owner, lack of communication between team members, miscalculated project budget by the owner, slow to respond to problems, reluctant to check construction regarding clarity and completeness.

Resolution strategies that must be applied to avoid conflicts with the owner factor are responding to problems in a timely manner, creating good communication between team members, creating clear mechanisms for providing information requests, creating good management, supervision and coordination, winning bidders as appropriate ( contractors and consultants), creating team spirit, routinely checking construction regarding clarity and completeness, appointing an appropriate project manager, asking for an explanation of the meaning in the contract documents when there is an error, ensuring the project budget by the owner in the correct calculation, making timely payments from the owner, ensuring the implementation of the contractor in accordance with the expectations of the owner, responsive in responding to problems, and approval of the value of the cost or pictures of proposals or program response to be resolved as soon as possible.

\section{Conclusion}

In the realization of construction projects in Aceh Province, one of the main factors causing conflict with the highest value is the factor of the project owner. The project owner factor has a value of 0,014 higher than the project condition factor. 


\section{Acknowledgement}

Acknowledgments the authors convey to all parties who have contributed to the research until the completion of this article was made.

\section{References}

[1] Ervianto, WI 2004, Teori Aplikasi Manajemen Proyek Konstruksi, Salemba Empat, Yogyakarta.

[2] Syah, M 2004, Kiat Manajer yang Sukses, Binapura Aksara, Jakarta.

[3] Dipohusodo, 1995, Manajemen Proyek \& Konstruksi Jilid 2, Kanasius, Yogyakarta.

[4] Ock, JH dan Han, SH 2003, Lesson Learned form Rigid Conflict Resolution in an Organization: Construction Conflict Case Study, Journal of Management in Engineering, April 2003.

[5] Susila, H., 2012, Faktor-faktor Penyebab Konflik dalam Pelaksanaan Proyek Konstruksi, Jurnal Teknik Sipil dan Arsitektur, Universitas Tunas Pembangunan Surakarta, Volume 11. No. 15, Maret 2012, ISSN: 2301-668X.

[6] Aderiani, R., Tantyonimpuno, S., dan Adi, W, J, T., 2005, Identifikasi Konflik yang Terjadi pada Pelaksanaan Proyek Konstruksi Gedung, Prosiding Seminar Nasional Manajemen Teknologi I, Program Studi Magister Manejemen Teknologi Institut Teknologi Sepuluh Nopember, ISBN: 979-99302-0-0.

[7] Priyatno, D 2010, Teknik Mudah dan Cepat Melakukan Analisis Data Penelitian dengan SPSS dan Tanya Jawab Ujian Pendadaran, Gaya Media, Yogyakarta.

[8] Ferdinand, A., 2006, Metode Penelitian Manajemen, Universitas Diponegoro, Semarang.

[9] Narbuko, C dan Achmadi, A 2004, Metodelogi Penelitian, Bumi Aksara, Jakarta.

[10] Sugiyono, 2015, Statistik Nonparametris untuk Penelitian, Alfabeta, Bandung.

[11] Soeharto, I., 2001, Manajemen Proyek-Dari Konseptual Sampai Operasional, Erlangga, Jakarta.

[12] Ranupandjojo, H., dan Husnan, S., 1994, Manajemen Personalia, BPEE, Yogyakarta. 